\title{
The Rise of Investor- State Public Health Disputes: Lessons Learned from the Idiosyncrasy of Argentinian and NAFTA Cases in the Era of COVID-19*
}

\author{
Munia El Harti Alonso ${ }^{1}$ \\ SOPHIA HERBST ${ }^{2}$
}

\section{ABSTRACT}

Argentina's prominence in the history of ISDS makes for a seminal case study of the tension between state measures and FDI. Argentina, like other Latin American countries, has taken a proactive approach to mitigating the current pandemic. Notably, these emergency public health decisions may hinder FDI, thus leading to an increase in investment disputes. This paper aims to comparatively analyze the past Argentinian crisis and health related NAFTA cases, using lessons learned to provide guidance in anticipation of COVID-19 disputes. In order to explore this topic, a discussion of jurisdictional and procedural questions allow for a modern application of past issues.

Keywords: COVID-19; NAFTA; Argentina, Latin America; Foreign Direct Investment/ $\mathrm{FDI}_{i}$ Arbitration, Public Health, Dispute Resolution, Emergency, Investment Disputes

1 Co-Author Munia El Harti Alonso is a Senior Clerk at Carballo Law LLP, focusing on international litigation of investment disputes in Latin America and Florida. Ms. El Harti Alonso can be reached atme725@georgetown.edu.

2 Co-Author Sophia Herbst is an Associate at the Law Offices of Charles Camp P.C., working primarily on international litigation and commercial arbitration. Ms. Herbst can be reached at sherbst@ law.gwu.edu.

* DOI: https://doi.org/10.18601/01236458.n56.05 


\section{RESUMEN}

La prominencia de Argentina en la historia del arreglo de diferencias relativas a inversiones internacionales (ISDS) permite un estudio de caso fundamental sobre la tensión entre las medidas estatales y la inversión extranjera directa (IED). Argentina, al igual que otros países latinoamericanos, ha adoptado un enfoque proactivo para mitigar la pandemia actual. En particular, estas decisiones de salud pública de emergencia pueden obstaculizar la IED, lo que conlleva a un aumento de las disputas de inversiones. Este artículo tiene como objetivo analizar comparativamente la crisis argentina pasada, y los casos del Tratado de Libre Comercio de América del Norte (TLCAN) relacionados con la salud publica, capitalizando sobre las lecciones aprendidas para proporcionar una guía en anticipación de las disputas de la covid-19. Para explorar este tema, una discusión sobre cuestiones jurisdiccionales y de procedimiento permite una aplicación moderna de cuestiones pasadas.

Palabras clave: covid-19, NAFTA, Argentina, Inversión Extranjera Directa/IED, arbitraje, salud pública, resolución de conflictos, emergencia, diferencias relativas a inversiones.

\section{INTRODUCTION}

While public health measures under the broader scope of the public order have been analyzed in the past, public health measures per se remain under-scrutinized in the context of the COVID-19 pandemic (Sheargold \& Mitchell, 2019; Warren-Clem, 2015; Voon, 2015; Korzun, 2017). Rather, current doctrine has focused on force majeure defenses, (Joshi, 2020; Mann \& Readhead, 2020) or procedural aspects such as virtual hearings (Scherer, 2020, pp.407-448). This article seeks to comparatively examine (i) Argentinian case law defining the contours of the notion of crisis and (ii) specific public health related North American Free Trade Agreement (NAFTA) decisions-using lessons learned to provide a predictive roadmap in anticipation of COVID-19 InvestorState disputes.

Argentina's prominence in the history of Investor-State Dispute Settlement (ISDS) makes for a seminal case study of the tension between state measures and Foreign Direct Investment (FDI). Argentina, like other Latin American countries, has made emergency public health decisions during the course of this pandemic, which may hinder FDI. The tension between FDI and the public order is exacerbated more than ever in the context of COVID-19. Consequently, this tension is increasing the risk of public health related disputes. In a status quo dynamic, the pandemic is set to give sovereigns an increased margin to regulate as they seek to mitigate the effects of the pandemic (Titi, 2014, p. 240). Foreseeing the rise of public health investment disputes, this article points to the idiosyncrasies of NAFTA and Argentinian investor-state cases. Both caseloads are axiomatic to predicting (Sections 2.1 and 2.2 of this article) and 
mitigating (Section 3 of this article) public health related disputes in the COVID-19 era that may arise in the coming years.

This article will first discuss the existing tensions between foreign direct investment and emergency measures enacted for the sake of the public order - including a discussion of state measures, which have been enacted as a result of the pandemic. Following this brief overview, this article will examine the notion of crisis through the lens of Argentinian cases stemming from the 2001-2002 crisis as well as NAFTA cases addressing public health measures in order to shed light on the interplay between public health measures and arbitration. Finally, mitigation of investor-state disputes in the COVID-19 era is discussed taking into account the lessons learned from Argentina and NAFTA.

\section{THE RISE OF INVESTOR-STATE PUBLIC HEALTH DISPUTES: AN EXACERBATED TENSION BETWEEN FDI AND THE PUBLIC ORDER}

The following section first aims to provide the reader with examples of measures states have been employing in efforts to address the COVID-19 pandemic. Some or all of these measures may find themselves to be the subject of disputes in the near future depending on how they have impacted foreign investors. Second, an overview of Argentinian and NAFTA cases will provide unique lenses through which we may make reasoned predictions of how COVID-19 related disputes will be treated. As discussed in more detail below, following Argentina's 2001 financial crisis, there was a rise in disputes filed against the state. While these cases may not have been related to public health measures, they paint a picture of what the next few years may look like following the public order decisions mentioned below.

\section{An Overview of State Measures Enacted as a Result of COVID-19: Putting States at Risk for Investor-State Public Health Disputes}

Latin American countries have opted for a proactive approach to the COVID-19 pandemic, with the enhancement of state powers in an attempt protect their residents. Notably, Chile, has entered into force a law providing protection for employees working from home or other temporary workspaces (Díez Pérez-Cotapos, 2020). In addition, as a result of the pandemic and the economic burden it has imposed, Chile opted to extend a power prize freeze originally enacted in 2019 (Bnamericas, 2020). Interestingly, when Peru considered suspending collection of toll fees in response to COVID-19, multiple officials came forward to warn of the potential ICSID cases that could arise from such a move (Sanderson, 2020). In Mexico, the administration reportedly "offered little financial support to big business" - a move that has also made it vulnerable to new claim (Strong, 2020; Benítez, Velásco et al., 2020; Sanderson, 2020). 
In Argentina, the Government has passed Law 27.254, which gives "intensified powers" to the government ${ }^{3}$. The Government then prolonged the national health emergency on 12 March 2020 with Decree 260/2020 to be in effect for one year. Further, on 21 August 2020, the Argentinean government announced it would extend its price freeze on gas, mobile, internet, and television services through the end of 2020, requiring any price increases to obtain government approval (Patrick Gillespie, 2020). The freeze encompasses "essential public services" and is added to the list of approximately 2,000 other consumer goods whose prices have been frozen as essential consumer goods. The examples provided from Chile, Peru, Mexico, and Argentina are representative of changes Latin American countries have taken in response to COVID-19 and, while they have had varying amounts of success in countering the pandemic, any number of them could form the basis of disputes in the future.

On the other side of the Atlantic, the European Union (EU) has taken similar approaches with the adoption of a variety of measures covering travel, coordinated treatment measures, large scale testing, and more (European Commission, 2020). In addition, on 13 October 2020, the EU Member States agreed to coordinate in order to restrict movement through the use of a common mapping system, consistent criteria across Member States for determining whether further restrictions are required, measures to be applied to travelers, and clear communication with the public (European Commission, 2020). More recently, on 11 November 2020, the European Commission began working towards the establishment of the European Health Union - intended to "strengthen the EU's health security framework" by using the current pandemic to strengthen the EU's response to future crises (European Commission, Nov. 2020). The proposals set forth through this Union may result in complications for investors in the future and are worth keeping an eye on.

The public health decisions mentioned above represent a mere handful of the changes States have enacted since the start of the pandemic. Any or all of these could lead to investor-state disputes in the future, depending on the impact they have had. Disputes of this nature are sure to arrive even after steps were taken to restrict FDI prior to the start of the pandemic. The EU, for example, set the stage over 18 months ago, for restrictions to FDI through a foreign investment screening mechanism, which, however, will undoubtedly play a role in the filing of new disputes related to the EU's

3 In a media release the Ministry of Justice of Argentina commented that "given the evolution of the pandemic, the National State's controls have been intensified to guarantee the rights contemplated in article 42 of the National Constitution (...)" (translated from Spanish by authors). http://www.saij.gob.ar/543-nacional-decreto-necesidad-urgencia-prorroga-plazo-180-diascorridos-para-mantener-tarifas-electricidad-gas-natural-suspension-corte-caso-mora-faltapago-servicios-energia-electrica-gas-redes-agua-corriente-telefonia-fija-movil-internet-tv-cable-vinculo-radioelectrico-satelital-dn20200000543-2020-06-18/123456789-0abc-345-00000202soterced?\&o=2\& $\mathrm{f}=$ Total\%7CFecha\%7CEstado\%20de\%20Vigencia\%5B5\%2C1\%5D\%7CTema\% 5B5\%2C1\%5D\%7COrganismo\%5B5\%2C1\%5D\%7CAutor\%5B5\%2C1\%5D\%7CJurisdicci\%F3n\%5B5 \%2C1\%5D\%7CTribunal\%5B5\%2C1\%5D\%7CPublicaci\%F3n\%5B5\%2C1\%5D\%7CColecci\%F3n\%20 tem\%E1tica\%5B5\%2C1\%5D\%7CTipo\%20de\%20Documento/Legislaci\%F3n/Decreto\&t $=46563$ 
handling of covid-19 (Berg, Ward et al., 2020; Love, 2020; Benedettelli, 2020; Moberg \& Hindelang, 2020, pp. 1427-60; UNCTAD, 2020; Simpson, 2020) .

When looking at the covid-19 responses of various states, there are certain measures which may pose a greater likelihood of being disputes including closures of "nonessential" businesses and other restrictions on businesses, preventing toll collection on toll roads, export restrictions on healthcare related items, and "occupation and intervention by health ministries" of health care related businesses (Lee, 2020, p. 187; Alcolea, 2020, p. 2). As discussed above, multiple of these examples do appear when examining state's actions. As noted by Alcolea when examining how these claims may be brought, it is likely they will be raised in claims of expropriation, breaches of fair and equitable treatment, and breaches of full protection and security (Alcolea, 2020, p. 3). Interestingly, the temporary nature of these measures may pose an obstacle for investors claims (Alcolea, 2020, p. 7).

Nevertheless, sovereigns are likely to continue exercising greater prerogatives in their regulatory capacity in an effort to curb the present pandemic and protect their residents. While an increasing number of disputes may arise over the coming months or years, States' leeway in enacting covid-19 restrictions, may also signify their greater capacity to defend disputes regarding those emergency measures, provided that such measures are properly crafted and enforced, meaning non-arbitrarily and proportionally (Diamond, 2020; Hodgson, 2020). A survey of 50 jurisdictions empirically demonstrated that most states enacted covid-19 measures in line with the WHO guidelines, making the success of defenses likely (Chaisse, 2020, pp. 99-184). To the contrary if the real purposes behind the regulatory measures are not for public health protection, but for other political considerations; or the implementation of the measures causes unjustifiable discriminations between domestic and foreign enterprises which are in like circumstances", the measure may breach the Fair and Equitable Treatment (FET) or National Treatment standards contained in Investment Agreements (Lo Mao Wei, 2020, p. 257).

\section{THE PRESCRIPTIVE ARGENTINIAN AND NAFTA INVESTMENT ARBITRATION CASE LAW}

Without diving into the "jurisprudence constante" debate, Argentina and NAFTA cases may serve as an optimal basis for assessing how public health measures taken during the covid-19 pandemic will be interpreted (Gillaume, 2011, pp. 5-23; Banifatemi, 2015, pp. 228-234). Taking stock of the Argentinian case law allows for a predictive

4 See Regulation (EU) 2019/452 of the European Parliament and of the Council of 19 March 2019 establishing a framework for the screening of foreign direct investments into the Union, https://eurlex.europa.eu/eli/reg/2019/452/oj (March 19, 2019) (Updated September 19, 2020); See also Royal Decree 664/1999, Of 23 April, On Foreign Investments; List of screening mechanisms notified by Member States, last updated 27 October 2020. https://trade.ec.europa.eu/doclib/docs/2019/june/ tradoc_157946.pdf. 
assessment of the contemporary notion of crisis in investor-state disputes. Concomitantly, the NAFTA cases are particularly informative towards the treatment of public health measures in such disputes.

\section{The Notion of Crisis Articulated in the Argentinian Cases: Necessity Reloaded}

The overwhelming majority of the Argentinian cases in which the notion of state measures taken during a national crisis was analyzed, perhaps except for Sempra II ${ }^{[5]}$ and $L G \& E^{[6]}$, were related to the emergency measures taken during the 2001-2002 crisis (Alvarez, 2012, pp. 5-6). The 1990s were a distinct high point in Argentina's history, but the late 1990s started off a confluence of events that led to Argentina's crisis. First, because the Argentinean peso had been pegged to the American dollar, when Brazil devalued the real, Argentina's exports and investments drastically decreased (Katel, 2001). Second, foreign and domestic debt was increased to the point that domestic interest rates went up and businesses were forced to close (Katel, 2001). Finally, as a result of increased privatization, including for utilities companies, prices for basics increased, people lost their jobs, and Argentina's recession spiraled uncontrollably (Katel, 2001). As a result of the Argentine government's response to this financial crisis, over forty cases were brought before ICSID asserting that the government measures had impaired investors' rights under Argentina's BITs (Burke-White, 2008).

As discussed by Jose Alvarez, the Argentinian cases have now come to a maturity that permits a "more sober" analysis - especially in 2020 and 2021 (Alvarez, 2012, p.3). The Argentinian investment arbitration decisions have been consistent in their approach to necessity and force majeure ("FM"), largely by denying the defenses alleged by Argentina (Burke-White, 2008). In agreement with Alvarez, we note that although necessity defenses were denied in those cases, ICSID remains "more the tool of the state than its enemy", (Alvarez, 2012, p.5) as demonstrated by the fact that states have prevailed in $52 \%$ of ICSID cases, and states continue to subscribe to ICSID in recent treaty drafting (ICSID Caseload Statistics, p. 14).

Here, the article does not aim to examine the defenses, but rather to draw attention to the crisis conceptualization by investment tribunals. The foreseen consequence is that, comparatively to the Argentinian cases, defenses are likely to prevail in the covid-19 context, provided that such cases involve measures enacted in an indiscriminate manner in light of the pandemic (Milan, 2020).

5 Sempra Energy International v. The Argentine Republic, ICSID Case n. ${ }^{\circ}$ ARB/02/16.

6 LG\&E Energy Corp. et al. v. Argentine Republic, ICSID Case n. ${ }^{\circ}$ ARB/02/1, Decision on Liability, 3 October 2006, par. 228. 
The Conceptualization of Crisis as Attributable to the State

In the paradigmatic Argentinean CMS case, the tribunal imputed the economic crisis situation to the state, and even the investor (CMS, Award 12 May 2005; Mobil, Decision on Jurisdiction and Liability 10 April 2013). The CMS panel noted, "[t]he question is, however, how grave these economic difficulties might be. A severe crisis cannot necessarily be equated with a situation of total collapse" (CMS, Award, 『354). However, should such difficulties arise, which "invite[s] catastrophic conditions in terms of disruption and disintegration of society, or are likely to lead to a total breakdown of the economy," the tribunal noted that "emergency and necessity might acquire a different meaning" (CMS, Award, 9354). The award concludes that "in the absence of such profoundly serious conditions, it is plainly clear that the Treaty will prevail plea of necessity" (CMS, Award, 9354). While the tribunal may not have seen Argentina's financial crisis as 'profoundly serious' enough, it is indisputable that the pandemic has caused a breakdown in society and the economy on a world-wide scale. Therefore, in contrast to the Argentinian factual background, the covid-19 pandemic likely falls within the "total collapse" scenario, identified by the tribunal in CMS.

CMS is also illustrative as the tribunal held that a state of necessity under domestic law did not offer an excuse to alter the substance or the essence of contractually acquired rights - especially if such measures are not made strictly temporary (CMS, Award 1217). We can extract a second differentiation, which is that the covid-19 pandemic is being tackled on a global scale ${ }^{7}$. The international nature of the covid-19 pandemic, in our view, circumvents the "domestic law" difficulty as regards the characterization of the crisis.

Taking into account the notion of 'crisis' articulated in the previously discussed Argentinian decisions, we can differentiate between, on the one hand, a financial and national crisis and, on the other, a global pandemic such as covid-19. The consequential prospect is for necessity defenses to prevail before arbitral tribunals in the covid-19 aftermath.

\section{Necessity More Likely to Prevail in the Pandemic Context}

Looking at the cases empirically, in 11 out of the 14 Argentinian cases where the state invoked necessity, the tribunal rejected that defense. The 11 decisions are respectively CMS, Enron, Sempra AWG Group, Suez, SAUR, EDF, BG Group, Continental Casualty, Total, El Paso, and Mobil Exploration ${ }^{8}$. The authors have identified three decisions that present

7 Declaration of the WHO Director General of 11 March 2020. https://www.who.int/es/dg/speeches/ detail/who-director-general-s-opening-remarks-at-the-media-briefing-on-covid-19-11-march-2020.

8 See CMS Gas Transmission Company v. Argentina, ICSID Case n. ${ }^{\circ}$ ARB/01/8, Award, 12 May 2005, para 217; Enron Creditors Recovery Corporation (formerly Enron Corporation) and Ponderosa Assets, L.P. v. Argentine Republic, ICSID Case n. ${ }^{\circ}$ ARB/01/3, Award, 22 May 2007, para 321; Sempra Energy International v. Argentine Republic, ICSID Case n. ${ }^{\circ}$ ARB/02/16, Award, 28 September 2007, para 346; AWG Group Ltd. v. Argentina, 
themselves as outliers, namely $L G \& E$, Urbaser and Total, whilst Casualty Company rejected the defense of measures aside of debt restructuring ${ }^{9}$. The three decisions are pertinent as they do not contradict the majority line, rather they are distinguishable as the facts were different. The tribunal in Total found that some of the disputed measures were after the emergency the state of emergency had passed (Total, \345). LG\&E is distinct from the 11 decisions, as "LG\&E has considered the situation in a different light and justified the invocation of emergency and necessity, albeit for a limited period of time" (Sempra citing to LG\&E, \346; Lucas Alcolea, 2020, p.24). The Urbaser tribunal similarly held that in January 2002, a state of necessity specifically existed (Urbaser, I718), cautioning that a state of necessity could not exist in perpetuity: "[w] hile the emergency measures were kept into force for many years and are allegedly still alive today, the necessity to do so has ceased to exist long before" (Urbaser, I719). Sempra and Enron are also worth mentioning as they were annulled, however not on a factual basis i.e. that a state of necessity was justified, but rather based on error and excess of powers in the interpretation of necessity based on ILC Article 25 ${ }^{[10]}$. Article 25 provides that:

1) Necessity may not be invoked by a State as a ground for precluding the wrongfulness of an act not in conformity with an international obligation of that State unless the act:

(a) IIs the only way for the State to safeguard an essential interest against a grave and imminent peril and;

(b) Does not seriously impair an essential interest of the State or States towards which the obligation exists, or of the international community as a whole.

UNCITRAL, Decision on Liability, 30 July 2010, para 258; Suez Sociedad General de Aguas de Barcelona S.A. and Vivendi Universal S.A v. Argentina, ICSID Case n. ${ }^{\circ}$ ARB/03/19, Decision on Liability, 30 July 2010, para 264-265; SAUR International v. Argentina, ICSID Case n. ${ }^{\circ} \mathrm{ARB} / 04 / 4$, Decision on Jurisdiction and Liability, 6 June 2012, paras 458-460; EDF International S.A., SAUR International S.A. and León Participaciones Argentinas S.A. v. Argentina, ICSID Case n. ${ }^{\circ}$ ARB/03/23, Award, 11 June 2012, para 1171; BG Group Plc. v. Argentina, UNCITRAL, Award, 24 December 2007, paras 411-412; Continental Casualty Company v. Argentine Republic, ICSID Case n. ${ }^{\circ}$ ARB/03/9, Award, 5 September 2008, for the debt restructuring measures, para 222; Total S.A.v. Argentine Republic, ICSID Case n. ${ }^{\circ}$ ARB/04/01, Decision on Liability, 27 December 2010, paras 482-484; El Paso Energy International Company v. Argentina (majority), ICSID Case n. ${ }^{\circ} \mathrm{ARB} / 03 / 15$, Award, 31 October 2011, paras 665-670; Mobil Exploration and Development Inc. Suc. Argentina and Mobil Argentina S.A. v. Argentine Republic, ICSID Case n. ${ }^{\circ}$ ARB/04/16, Decision on Jurisdiction and Liability, 10 April 2013, para 1124.

9 LG\&E Energy Corp., LG\&E Capital Corp. and LG\&E International Inc. v. Argentina (ICSID Case n. ${ }^{\circ}$ ARB/02/1), Award, July 25, 2007; Urbaser S.A. and Consorcio de Aguas Bilbao Biskaia, Bilbao Biskaia Ur Partzuergoa $v$. Argentina, Award, 8 December 2016, para 718; Total S.A. v. Argentina, ICSID Case n. ${ }^{\circ}$ ARB/04/01, Decision on Liability, 27 December 2010, para 484, Casualty Company v. Argentina, ICSID Case n. ${ }^{\circ}$ ARB/03/9, Award, 5 September 2008, para 236.

10 See ILC Articles on Responsibility of States for Internationally Wrongful Acts, Article 25. 
(2) In any case, necessity may not be invoked by a State as a ground for precluding wrongfulness if: (a) The international obligation in question excludes the possibility of invoking necessity; or

(b) The State has contributed to the situation of necessity.

"Unlike in Enron and Sempra, where the tribunal was not convinced that the economic crisis was so dire as to compromise "the very existence of the State and its independence" (Enron, Award 27 May 2007, 『306; Sempra, Award 28 September 2007, 『348) the current pandemic has threatened more than States' economies, but also the very lives of their residents. Most notably, the tribunal found there to be "no convincing evidence that the events were out of control or had become unmanageable" (Enron Award, 『307; Sempra, Award, 『349). It is more than likely that States will be able to, quite convincingly, argue that the pandemic was entirely out of control and unmanageable when they felt it necessary to enact various regulations. Finally, the Enron tribunal was able to compare Argentina's handling of the crisis with other States' economic crises - demonstrating that Argentina had many other approaches available (Enron Award, I308; Sempra, Award, 9350). On the contrary, the last pandemic was the H1N1 outbreak of 2009, which, although rapidly transmitted, was significantly less impactful than covid-19 has been to date. Therefore, States' responses to H1N1 will not likely be used to undermine their responses to covid-19 - liminating yet another barrier brought up in the Argentinian cases.

Authors have pointed out the problematic "split" in the 11 decisions versus the outliers, (Reinisch, 2006) however in a holistic approach, the abovementioned 'outliers' remain marginal in comparison to the majority. As shown from the cases discussed and cited above, national or global crisis aside, States must still justify measures taken. From a tactical standpoint, States will still bear the burden of proof as found in Impregilo (Impreglio, Award 21 June 2011, \345). The Argentinian cases are comparatively informative: since the crisis in Argentina was differentiable from the pandemic, the necessity defense is more likely to prevail at the liability stage in upcoming covid-19 related arbitrations.

\section{NAFTA Cases as A Precise Indicator: A Unique Specificity in Public Health Investment Arbitration Case Law}

The authors have identified that NAFTA cases present a unique measure to best evaluate with specificity public health disputes in the realm of investment arbitration. The specificity of NAFTA cases is denoted from the fact that (1) most NAFTA cases concern public health, and (2) looking at the bigger picture, the majority of all public health investment arbitration decisions are found in NAFTA cases. While the Argentina case decisions call for extrapolation from a financial crisis to a public health crisis, the 
public health related NAFTA decisions allow for a unique basis of comparison with current events.

\section{NAFTA Cases Specifically Address Public Healtb Measures}

As discussed above, NAFTA cases most commonly concern public health decisions and their impacts on investors. NAFTA tribunals have consistently held a restrictive interpretation of the minimum standard of treatment of NAFTA Article 1105 (J-C Thomas 2002, pp. 21-101), setting again a high bar for the investor (Apotex, Award 25 August, 2014; Chemtura, Award 2 August 2010). Article 1105 on the minimum standard of treatment provides that:

1. Each Party shall accord to investments of investors of another Party treatment in accordance with international law, including fair and equitable treatment and full protection and security.

2. Without prejudice to paragraph 1 and notwithstanding Article 1108(7)(b), each Party shall accord to investors of another Party, and to investments of investors of another Party, non-discriminatory treatment with respect to measures it adopts or maintains relating to losses suffered by investments in its territory owing to armed conflict or civil strife.

The cases under analysis in this article include Apotex, Chemtura, Metbanex, Grand River and Glamis ${ }^{11}$. The tribunal in Apotex highlighted the importance of the previous NAFTA decisions, albeit their lack of res judicata force the "other decisions indicate the need for international tribunals to exercise caution in cases involving a state regulator's exercise of discretion, particularly in sensitive areas involving protection of public health and the well-being of patients" (Apotex, 99.37).

A comprehensive look at the NAFTA cases involving public health measures, will assist in our assessment of how states are likely to be treated in upcoming covid-19 related disputes ${ }^{12}$. It is also worth acknowledging that, while the United

11 See Apotex Holdings Inc. and Apotex Inc. v. United States of America, ICSID Case n. ${ }^{\circ}$ ARB(AF)/12/1, Award, 25 August 2014; Chemtura Corporation v. Government of Canada, UNCITRAL (formerly Crompton Corporation v. Government of Canada), Award, 2 August 2010; Methanex Corporation v. United Stated of America, UnCitral, Final Award of the Tribunal on Jurisdiction and Merits, 3 August 2005; Grand River Enterprises Six Nations, Ltd. And others v. United States of America, UNCITRAL, Award, 12 January 2011; Glamis v. United States, UnCITRAL, Final Award 8 June 2009.

12 See Apotex Holdings Inc. and Apotex Inc. v. United States of America, ICSID Case n. ${ }^{\circ}$ ARB(AF)/12/1, Award, 25 August 2014; Chemtura Corporation v. Government of Canada, UNCITRAL (formerly Crompton Corporation v. Government of Canada), Award, 2 August 2010; Methanex Corporation v. United Stated of America, UnCITRAL, Final Award of the Tribunal on Jurisdiction and Merits, 3 August 2005; Grand River Enterprises Six Nations, Ltd. And others v. United States of America, UNCITRAL, Award, 12 January 2011; See also, Glamis v. United States, UNCITRAL, Final Award 8 June 2009-included here because the Tribunal in Pbillip Morris $v$. Uruguay referred to Glamis when stating that the only inquiry that the tribunal 
States-Mexico-Canada Agreement (the "USMCA") entered into force on July 1, 2020, restricting access to investor-state arbitration, investors will still be able to file NAFTA claims before July 1, 2023 provided that the dispute arises out of investments made while NAFTA was still in force ${ }^{13}$. Disputes arising out of covid-19 measures, will most likely involve such "legacy investments."

NAFTA Tribunals' Interpretation of Public Health Measures:

A Wide and Particular Regulatory Space to the State

NAFTA tribunals, in line with the Notes of Interpretation issued by the $\mathrm{FTC}^{14}$, have consistently held a restrictive interpretation of the minimum standard of treatment of NAFTA Article 1105, setting a high bar for the investor (Brower II, 2006, pp. 347-364; Kaufmann-Kohler, 2011, p. 20).

Referencing the Thunderbird decision (which concerned gambling), (Thunderbird, 9127) the Apotex tribunal restated the "wide regulatory space for regulation" in the context of a NAFTA Chapter 11 interpretation (Apotex, 99.38). Regarding the trade of drug products, the decisions considered the "particular regulatory context, involving imports of drug products potentially bearing serious risks to public health". In the case of a drug shortage, which is already happening with covid-19, the Apotex tribunal refused to uphold the national treatment protection for a foreign drug manufacturer (FDA Insight).

NAFTA Tribunals also considered whether the claimant operated in a highly regulated sector (i.e. public health) to weigh the legitimate expectations. This was the case in Chemtura, whereby the tribunal stated that: "the rule [sic: role] of a Chapter 11 Tribunal is not to second-guess the correctness of a science-based decision-making of highly specialized national regulatory agencies" (Chemtura, $\$ 134)$. Practically, investors might have to first pursue local remedies to assert an FET violation, as was found in the Apotex decision relating to a drug import alert. The new USMCA similarly includes a requirement to litigate disputes for 30 months (Annex 14-D) before local courts, one of the new Treaty's procedural safeguards for USMCA host states" (Shirlow \& Gore, 2020). As regards the expropriation and compensation provisions, Annex 14-B of the USMCA requires tribunals to consider "that non-discriminatory regulatory actions designed to further legitimate public welfare objectives are not, except in rare circumstances, violations" (Hodgson, 2020). As Melida Hodgson points out, it is unclear if the USMCA

needed to make was whether there was a manifest lack of reasons for the legislation. In addition, although concluded before the liability phase, Dow AgroSciences LLC v. Government of Canada, UNCITRAL, Settlement Agreement 25 May 2011 and Ethyl Corporation v. Government of Canada, UNCITRAL, Award on Jurisdiction 24 June 1998, were claims brought related to public health measures.

13 The United States-Mexico-Canada Agreement, Annex 14-C Legacy Investment Claims and Pending Claims, entered into force 1 July 2020.

14 The FTC Commission for NAFTA adopted the Notes of Interpretation in 2001, aiming at restricting the meaning of Article 1105 to the requirements of customary international law. 
will include the Notes of Interpretation, which has significantly crafted the NAFTA case law (Hodgson, 2020). What is predictable is a surge in NAFTA claims in the next 3 years, before its termination.

\section{MITIGATION OF ISDS DISPUTES IN THE COVID-19 CONTEXT}

Taking into account the increasing margin of appreciation of states in the ISDS and covid-19 context, the authors suggest several considerations for the mitigation of disputes. Thus far, reported ISDS disputes based on covid-19 measures have not been filed $^{15}$. However, existing proceedings have been affected by either challenges to the tribunal (Sanderson, 2020) ${ }^{16}$, or a suspension of the arbitration ${ }^{17}$. In the latter instance, the Glencore tribunal opted for an equitable approach, granting a partial extension for the state. The panel noted it "cannot ignore the effects of the current global health crisis and, on the other hand, it must also ensure equal treatment" (Glencore, Procedural Order $\left.{ }^{\circ}{ }^{\circ} 11, \mathbb{9} 17\right)$. It is worth noting that a Force Majeure argument is unlikely to succeed for written submissions, as recalled by the tribunal in a recent PCA case whereby "[it was] comforted in that regard by the practice in other proceedings, where written submissions may have been delayed, within reason, and hearings may have been re-scheduled (or held online), but the proceedings have not been suspended or ruled impossible to continue" (Agreda, Procedural Order n. ${ }^{\circ}$ 7, 10 April 2020, \38).

The effects of the pandemic span as far as to the enforcement stage. In the recent Union Fegosa v. Egypt case, the tribunal ordered a stay of the proceedings in view of the ( 2 Billion USD) size of the award and the "uncertainties regarding an unprecedented global pandemic" (Union Fenosa, Memorandum Opinion 4, June 2020, \21). Procedural issues will become of paramount importance in the pandemic, moreover as regards their substance. In BSG $v$. Guinea the tribunal allocated $75 \%$ of the advance on arbitration costs to be borne by the claimant. In doing so, the panel took into consideration that the country was facing the Ebola crisis (BGS, Procedural Order n. ${ }^{\circ} 3$, \67).

In view of the difficulties states are facing, some fora have called for a complete moratorium on investor-state disputes during the pandemic (Call for ISDS Moratorium, 2020). More pragmatically, mediation has been promoted by ICSID for investor-state disputes (ICSID Mediations; Nitschke, 2020; Fach \& Titi, 2019, p. 416). The ICSID Rules

15 From January 1, 2020 until June 30, 2020, 23 cases have been registered by ICSID under the ICSID Convention and Additional Facility Rules. However, none of these registered matters concern measures taken during the pandemic. See The ICSID Caseload-Statistics, Issue 2020-2.

16 See Landesbank Baden-Württemberg and others v. Kingdom of Spain, ICSID Case n. ${ }^{\circ}$ ARB/15/45 12 August 2020 Respondent files a proposal for disqualification of the three members of the Tribunal. The proceeding is suspended in accordance with ICSID Arbitration Rule 9(6).

17 See Glencore Finance (Bermuda) Limited v. Plurinational State of Bolivia, PCA Case n. ${ }^{\circ}$ 2016-39, Procedural Order n. ${ }^{\circ}$ 11, 5 May 2020: By letter dated 23 April 2020, the Respondent requested that the Tribunal suspend this arbitration and, subsequently, requested an additional 8-week extension (until 13 July 2020) of the deadline to submit its Rejoinder on Quantum as a result of the COVID-19 pandemic (the "Request"), par. 4. 
already timidly (Echandi \& Kher, 2014, pp. 41-65) provide for mediation within Rule 43(2) whereby the parties can ask the Tribunal to render an award embodying the settlement agreement ${ }^{18}$. With the Singapore Convention on Mediation now open for signature ${ }^{19}, \mathrm{ADR}$ is set to come into prominence in the near future of ISDS (Kessedjian, 2020). On the other hand, Spain has opted for an interesting settlement tactic, using the carrot rather the stick; the Kingdom successfully asked investors to abandon their arbitration claims or enforcement actions with an assurance to keep a reasonable rate of return of 7.398\% (CIAR Global Editorial Staff, 2020; Riaño, 2019; Perez-Salido, 2019). A fortiori, settlement and mediation as alternative mechanisms in ISDS are prone to become increasingly relevant in the covid-19 context.

\section{CONCLUSION}

This article sought to approach the idea of investor-state disputes in the covid-19 era through a discussion and analysis of two caseloads. The analysis harnesses lessons learned from the Argentina and NAFTA experiences, which, much like the ISDS, have now gained an ascertainable maturity. The breadth of case law importantly provides predictability for all stakeholders when attempting to ascertain whether new cases will be arising from States' pandemic response measures. Argentina is exemplary of a state with extensive know-how in ISDS, defending an important number of arbitration disputes through the State's "Procuración" ${ }^{20}$. While Argentina may not have had a great deal of success in defending these disputes as the tribunals did not find the financial crisis to be severe enough to warrant the measures taken, the reasoning provided in the various awards points to States being more successful should they find themselves defending against a specific covid-19 related dispute. The covid-19 pandemic

ICSID Rule 43 on Settlement and Discontinuance: "[i]f the parties file with the Secretary-General the full and signed text of their settlement and in writing request the Tribunal to embody such settlement in an award, the Tribunal may record the settlement in the form of its award".

United Nations Convention on International Settlement Agreements Resulting from Mediation (New York, 2018) (the "Singapore Convention on Mediation"), adopted on 20 December 2018 and open for signature since 7 August 2019.

20 Egypt also has gained extensive experience in defending disputes with a specialized body for arbitration, it notably settled 17 out of 25 ICSID cases. See also, Bakry, A. (2020) After 48 Years at ICSID (1972-2020): An Overview of the Status of Egypt in ICSID Arbitrations: "To avoid significant potential financial awards, Egypt successfully concluded 14 settlements during the period 1992-2020 (i.e. $56 \%$ of the total concluded cases). It is worth noting that Egypt concluded 11 of the settlements (i.e. 78\%) during the period 2014-2020, following the establishment of the Committee for the Settlement of Investment Contracts Disputes as an alternative out-of-court forum to amicably settle investment disputes. Interestingly, 9 of the cases (i.e. 69\%) were discontinued according to article 43(1) ICSID Arbitration Rules, based on the request of both parties". http://arbitrationblog.kluwerarbitration.com/2020/03/15/after-48-years-at-icsid-1972-2020-an-overview-of-the-status-of-egypt-inicsid-arbitrations/\#: :text=Since\%20the\%202011\%20Egyptian\%20revolution,since\%20joining\%20 the\%20ICSID\%20Convention.\&text=Egypt\%20has\%20concluded\%2098\%20Bilateral,refer\%20 to $\% 20$ the $\% 20$ ICSID $\% 20$ Convention. 
has presented the entire world with novel challenges and has threatened economies, lives, and more. While States will still bear the burden of proof in these matters, it seems that States will have better odds of successfully harboring necessity defenses.

Similarly, the United States has gained substantial expertise in successfully defending NAFTA cases (Rabson, 2017; Gantz, 2019). The above discussion of NAFTA decisions, which have dealt with public health measures, serves as a direct reflection of how covid-19 health measures may be treated in upcoming arbitration disputes. Investors have come up against a high bar when attempting to raise minimum standard of treatment claims, which, in combination with the lessons learned from the Argentinian cases, suggests that the upcoming pandemic related disputes will also pose difficulty to investors. Ultimately, sovereigns might be better positioned to either seek alternative settlements, or to assert their right to regulate in a genuine case of necessity. The scenario is not as dark as depicted, as states, more than ever, hold cards in the investor-states dispute settlement system.

\section{REFERENCES}

\section{Books}

Sheargold, M., \& Mitchell, A. (2019). Public Health in International Investment Law and Arbitration.

TiTI, C. and FACH, K. (2019). Mediation in International Commercial and Investment Disputes, OUP.

TITI, C. (2014). The Right to Regulate in International Investment Law.

\section{Articles}

AlcoleA, L. C. (2020). The COVID-19 Crisis: Core Investment Law Issues Revisited. Transnational Dispute Management.

AlvareZ, J. (2012). The Paradoxical Argentina Cases. World Arbitration and Mediation Review 6(3). BAKRY, A. (2020). After 48 Years at ICSID (1972-2020): An Overview of the Status of Egypt in ICSID Arbitrations. Kluwer Arbitration Blog.

Banifatemi, Y. (2015). The Long March Towards a Jurisprudence Constante on the Notion of Investment. Building International Investment Law: The First 50 Years of ICSID, Kluwer.

BenedeTtelli, M. (2020). Could COVID-19 emergency measures give rise to investment claims? First reflections from Italy. Global Arbitration Review.

BeníteZ, M., VelÁsco C., et al. (2020) Responses to COVID-19 in five Latin American countries. Healtb Policy and Tecbnology 9(4).

BerG, N., Ward, D., Gregor, K. \& Gilley, E. (2020). Covid-19 Measures: Leveraging Investment Agreements to Protect Foreign Investments. Ropes \& Gray Coronavirus Information and Updates.

BNAMERICAS (2020). Coronavirus to worsen fallout from Chile's power price freeze. Bnamericas. 
Brower, II C. (2006). Why the FTC Notes of Interpretation Constitute a Partial Amendment of NAFTA Article 1105. Virginia Journal of International Law.

Burke-White, W. (2008). The Argentine Financial Crisis: State Liability Under BITs and the Legitimacy of the ICSID System. Faculty Scholarship at Penn Law.

Cariola Díez Pérez-Cotapos (2020). Chile: New legal regulations related to working remotely. L\&E Global.

Chaisse, J. (2020). Both Possible and Improbable-Could COVID-19 Measures Give Rise to Investor-State Disputes? Contemporary Asia Arbitration Journal, 13(1).

CIAR Global Editorial Staff (2020). Nuevos inversores de renovables abandonan arbitrajes contra España. CIAR Global.

Diamond, Nicholas, J. (2020). Pandemics, Emergency Measures, and ISDS. Kluwer Arbitration Blog.

EChandi, R., \& KHER, P. (2014). Can International Investor-State Disputes be Prevented? Empirical Evidence from Settlements in ICSID Arbitration. ICSID Review - Foreign Investment Law Journal, $29(1)$.

European Commission (November 2020). Building a European Health Union: Stronger crisis preparedness and response for Europe. Press Release.

GantZ, D. (2019). The United States-Mexico-Canada Agreement: Settlement of Disputes. Rice University's Baker Institute for Public Policy Report.

Gillaume, G. (2011). The Use of Precedent by International Judges and Arbitrators. Journal of International Dispute Settlement, 2(1).

Gillespie, P. (2020). Argentina Freezes TV, Internet and Mobile Prices Until Year-End. Bloomberg News.

Hodgson, M. (2020). The USMCA/CUSMA/T-MEC's Entry into Force: USMCA and U.S. Investors - A Reversal of Fortune? Kluwer Arbitration Blog.

Hodgson, M. (2020). La pandemia del COVID-19 y el impacto de las medidas de protección sobre las obligaciones internacionales de los Estados en materia de inversion. Jenner \& Block: Arbitraje Internacional.

Joshi, R. (2020). Force Majeure under the ILC Draft Articles on State Responsibility: Assessing its Viability Against COVID-19 Claims. American Society of International Law Insigbts, 24(24).

Katel, P. (2001). Argentina's Crisis Explained. Time Magazine.

Kaufmann-Kohler, G. (2011). Interpretive Powers of the Free Trade Commission and the Rule of Law. IIA Series n. ${ }^{\circ} 7$.

Kessedjian, C. et al. (2020). Mediation in Future Investor-State Dispute Settlement. Academic Forum on ISDS Concept Paper 2020/16.

Korzun. V. (2017). The Right to Regulate in Investor State Arbitration: Slicing and Dicing Regulatory Carve-Outs. FLASH: The Fordham Law Archive of Scholarship and History 50.

LEE, J. (2020). The Coronavirus Pandemic and International Investment Arbitration-Application of "Security Exceptions" Clauses in Investment Agreements. Contemporary Asia Arbitration Journal, 13(1). 
LOVE, B. (Spring, 2020). Consideration of State responsibility for investment treaty violations during the COVID-19 pandemic. Reed Smith International Arbitration Focus: Investor State Arbitration.

ManN, H., \& ReAdHEAD, A. (May 2020), Force Majeure and COVID-19: Legal risks of a double edged-sword. International Institute for Sustainable Development.

MaO-WeI, L. (2020). Legitimate Expectations in a Time of Pandemic: The Host State's COVID-19 Measures, Its Obligations and Possible Defenses Under International Investment Agreements. Contemporary Asia Arbitration Journal, 13(1).

Milan, L. (2020). COVID-19 and the risk of foreign investor challenges. The Canadian Bar Association National Magazine.

MoberG, A., \& Hindelang, S. (2020). The art of casting political dissent in law: The Eu's framework for the screening of foreign direct investment. Common Market Law Review 57(5).

NiTSCHKE, F. (2020). ICSID's Role in Advancing Investor-State Mediation. Global Arbitration Review. Perez-Salido, P. (2019). Royal Decree-Law 17/2019: An Opportunity for Spain to Leave Behind the Renewable Energy Arbitrations? Kluwer Arbitration Blog.

RABSON, M. (2017). NAFTA lawsuits target Canada most while U.S. hasn't lost yet. The Canadian Press Financial Post.

ReINISCH, A. (2006). Necessity in International Investment Arbitration - An Unnecessary Split of Opinions in Recent ICSID Cases? Comments on CMS v. Argentina and LG\&E v. Argentina. Transnational Dispute Management.

Riaño, M., PaZ, I., Claviño I., \& Ramón, J. (2019). Spain Approves Royal Decree-Law 17/2019, of 22 November, which establishes the new rate of reasonable return for renewable energy. Lexology.

SANDERSON, C. (2020). Peru warned of potential ICSID claims over covid-19 measures. Global Arbitration Review.

SANDERSON, C. (2020). ICSID panel challenged over decision to hold virtual hearing. Global Arbitration Review.

SANDERSON, C. (2020). Mexico faces potential claims over pandemic response. Global Arbitration Review.

SCHERER, M. (2020). Remote Hearings in International Arbitration: An Analytical Framework. Journal of International Arbitration, Kluwer Law International, 3(4).

Shirlow, E., \& GORE, K. (2020). The USMCA/CuSMA/T-MEC's Entry into Force: Evolution, Innovation, and Reform. Kluwer Arbitration Blog.

Simpson, C. (2020). Third-Party Funders' Business is Booming During Pandemic. Law 360.

Strong, G. (2020). Opportunities Abound in Latin America for Distressed Asset Investors. Forbes.

Thomas, J. C. (2002). Reflections on Article 1105 of NAFTA: History, State Practice and the Influence of Commentators. ICSID Review - Foreign Investment Law Journal, 17(1).

United Nations UnCTAD (2020). Investment Policy Responses to the COVID-19 Pandemic. Investment Policy Monitor.

United Nations UNCTAD (2020). Investor-State Dispute Settlement Cases Pass the 1,000 Mark: Cases and Outcomes in 2019. IIA Issues Note. 
Voon, T. (2015). Evidentiary Challenges for Public Health Regulation in International Trade and Investment Law. Journal of International Economic Law, 18(4).

Warren-Clem, A. (2015). PMi v. Uruguay: Public Health and Arbitration Intertwined and Undermined. Law and Business Review of the Americas, 21(4).

\section{Cases}

Apotex Holdings Inc. and Apotex Inc. v. United States of America, ICSID Case n. ${ }^{\circ}$ ARB $(\mathrm{AF}) / 12 / 1$.

AWG Group Ltd. v. The Argentine Republic, ICSID Case n. ${ }^{\circ}$ ARB/03/19.

BG Group Plc. v. The Argentine Republic, UnCITRAL.

BGS Resources, Ltd. V. Republic of Guinea, ICSID Case n. ${ }^{\circ}$ ARB/14/22.

Continental Casualty Company v. The Argentine Republic, ICSID Case n. ${ }^{\circ}$ ARB/03/9.

Chemtura Corporation v. Government of Canada, Ad Hoc under UNCITRAL.

CMS Gas Transmission Company v. The Argentine Republic, ICSID Case n. ARB/01/8.

Dow AgroSciences LLC v. Government of Canada, UNCITRAL.

EDF International S.A., SAUR International S.A. and León Participaciones Argentinas S.A. v. The Argentine Republic, ICSID Case n. ${ }^{\circ}$ ARB/03/23.

El Paso Energy International Company v. The Argentine Republic (majority), ICSID Case n. ${ }^{\circ} \mathrm{ARB} / 03 / 15$.

Enron Creditors Recovery Corporation (formerly Enron Corporation) and Ponderosa Assets, L.P. v. The Argentine Republic, ICSID Case n. ${ }^{\circ} \mathrm{ARB} / 01 / 3$.

Etbyl Corporation v. Government of Canada, UNCITRAL.

Glamis $v$. United States, UNCITRAL.

Glencore Finance (Bermuda) Limited v. Plurinational State of Bolivia, PCA Case n. ${ }^{\circ}$ 2016-39.

Grand River Enterprises Six Nations, Ltd. And others v. United States of America, UNCITRAL.

Impregilo S.p.A. v. The Argentine Republic, ICSID Case n. ${ }^{\circ}$ ARB/07/17.

Landesbank Baden-Württemberg and others $v$. Kingdom of Spain, ICSID Case n. ${ }^{\circ}$ ARB/15/45.

LG\&E Energy Corp. et al. v. The Argentine Republic, ICSID Case n. ${ }^{\circ} \mathrm{ARB} / 02 / 1$.

Methanex Corporation v. United Stated of America, UNCITRAL.

Mobil Exploration and Development Inc. Suc. Argentina and Mobil Argentina S.A. v. The Argentine Republic, ICSID Case n. ${ }^{\circ}$ ARB/04/16.

SAUR International v. The Argentine Republic, ICSID Case n. ${ }^{\circ} \mathrm{ARB} / 04 / 4$.

Sempra Energy International v. The Argentine Republic, ICSID Case n. ${ }^{\circ} \mathrm{ARB} / 02 / 16$.

Suez Sociedad General de Aguas de Barcelona S.A. and Vivendi Universal S.A v. The Argentine Republic, ICSID Case n. ${ }^{\circ} \mathrm{ARB} / 03 / 19$.

The Estate of Julio Miguel Orlandini-Agreda \& Compañia Minera Orlandini Ltda. V. The Plurinational State of Bolivia, PCA Case n. ${ }^{\circ}$ 2018-39.

Total S.A. v. The Argentine Republic, ICSID Case n. ${ }^{\circ} \mathrm{ARB} / 04 / 01$.

Unión Fenosa Gas, S.A. v. Arab Republic of Egypt, ICSID Case n. ${ }^{\circ}$ ARB/14/4.

Urbaser S.A. and Consorcio de Aguas Bilbao Biskaia, Bilbao Biskaia Ur Partzuergoa v. The Argentine Republic, ICSID Case n. ${ }^{\circ} \mathrm{ARB} / 07 / 26$. 


\section{Websites}

Columbia Center on Sustainable Development (May 2020). Call for ICSID Moratorium During COVID-19 Crisis and Response. http://ccsi.columbia.edu/2020/05/05/isds-moratoriumduring-covid-19/.

European Commission (October 2020). Coronavirus Response. https://ec.europa.eu/info/ live-work-travel-eu/coronavirus-response_en.

FDA Insight: Drug Shortages and COVID-19. https://www.fda.gov/news-events/fda-insight/ fda-insight-drug-shortages-and-covid-19.

ICSID Caseload Statistics (Issue 2020-2). https://icsid.worldbank.org/sites/default/files/publications/The\%20ICSID\%20Caseload\%20Statistics\%20\%282020-2\%20Edition\%29\%20 ENG.pdf.

ICSID, Mediations. https://icsid.worldbank.org/services-arbitration-investor-state-mediation. 